\title{
ОСОБЛИВОСТІ ВИЯВУ КОПІНГ-СТРАТЕГІЙ ОСОБИСТОСТІ, ЩО ЗАЗНАЛА ВПЛИВУ ТРАВМАТИЧНОЇ СИТУАЦЇ̈
}

Статтю присвячено дослідженню особливостей копінг-стратегій особистості, що зазнала впливу травматичної ситуації. Показано, що копінг-стратегії особистості є ефективним ресурсом подолання наслідків травми. Підкреслюється, що дієвість опанування складної ситуації проявляється в узгодженості копінгстратегій з факторами вияву життєздатності та ресурсів життєстійкості особистості. Зауважено, що травматичні події спричиняють активацію ресурсів життєздатності, які виконують реабілітаційну функцію щодо збереження та відновлення психологічного здоров'я особистості. Емпірично встановлено, що конфронтаційність, готовність до ризику в поєднанні з готовністю відстоювати активну громадянську позицію $є$ адекватною щодо революційної ситуації стратегією подолання та нейтралізації зовнішніх руйнівних факторів, однак така стратегія може спричиняти водночас підвищений ризик емоційного вигоряння. Копінг-стратегію "втеча-уникнення" розглянуто як певний вияв емоційної ригідності, що може перешкоджати адекватній когнітивній оцінці ситуації та інтеграції травматичного досвіду свідомістю, а також уповільнювати процеси нормальної життєпобудови. Наголошується, що особливої уваги 3 погляду психологічних інтервенцій потребує вікова категорія громадян віком 35-45 років. Зроблено висновок, що пошук соціальної підтримки є універсальним копінгресурсом подолання наслідків травматичних подій, а середній і високий рівень сформованості компетенцій життєстійкості зумовлює високу ефективність використання проблемно орієнтованих копінг-стратегій.

Ключові слова: копінг-стратегії, життєздатність, опанування, травма.

T. O. Larina

\section{THE FEATURES OF THE COPING STRATEGIES MANIFESTATION IN PERSONALITY AFFECTED BY A TRAUMATIC SITUATION}

The article is dedicated to the study of the coping strategies features of the person experiencing the consequences of traumatic events. It is shown that coping strategies of individual is an effective resource to overcome the trauma consequences. It is emphasized that the effectiveness of overcoming the difficult situation manifests itself through the coping strategies coherence with the factors of resilience and hardiness resources. It is noted that traumatic events lead to the activation of resilience resources which play the rehabilitation function in the individual's psychological health preserving and restoring. It is empirically determined that confrontationality, willingness to risk combined with willingness to defend an active civic position are adequate in a revolutionary situation as a strategy for overcoming and neutralizing of external destructive factors. However, such a strategy may lead to an increased risk of emotional burnout. The escape-avoidance coping strategy is seen as a certain manifestation of emotional rigidity, which can hinder an adequate cognitive assessment of the situation and an integration of traumatic experiences into consciousness, as well as slow down 
the mechanisms of normal life-formation. It is emphasized that special attention should be required to the psychological interventions of the 35-45 y. o. age category. It is summarized that the search for social support is a universal coping resource for overcoming traumatic events, and that the average and high levels of hardiness competencies determine high efficiency of using problem-oriented coping strategies.

Key words: coping strategies, resilience, overcoming, trauma.

Постановка проблеми. Події, пов’язані з розв'язанням РФ гібридної війни проти України, спричинили цілу низку життєвих викликів і травматичних подій, на які потрібно вчасно реагувати та витрачати на їх опанування величезний арсенал адаптаційних ресурсів. За таких умов проблема дослідження ресурсів особистості, які допомагають протидіяти руйнівним наслідкам травми, використовувати ефективні стратегії опанування труднощів, керувати власними адаптаційними можливостями, набуває все більшої актуальності. Окремий інтерес становить вивчення копінг-стратегій як елементів свідомої поведінки, за допомогою якої людина намагається впоратись із життєвими труднощами $[1 ; 2]$, осмисленої діяльності, спрямованої на активну взаємодію із ситуацією; можливостей змінити ситуацію, якщо вона піддається контролю, або пристосуватися до ситуації, якщо вона неконтрольована [3].

Аналіз останніх досліджень і публікацій. Науковці наголошують, що різні ситуації вимагають застосування різних стратегій опанування (або їх поєднання) [4]. Розглядаючи фактори подолання травм і фактори посттравматичного зростання, звертають увагу на особливу роль вибору копінг-стратегій у складних ситуаціях [5].

3 ресурсної теорії С. Е. Хобфолла, до якої все частіше звертаються науковці, котрі вивчають копінг, випливає, що зберегти здоров'я та адаптуватися за тяжких життєвих обставин можна завдяки “розподілу ресурсів”, які впливають на копінгову поведінку особистості [6]. Отже, сучасні дослідження, присвячені проблемі ефективного відновлення та реабілітації особистості після травми, усе більше зосереджують увагу не так на наявності ресурсів опанування, як на їх ефективному використанні і на здатності узгоджувати ресурси власного психологічного здоров'я, розвиваючи власну мужність та впевненість щодо конструктивного подолання стресу.

Провідну роль у конструктивному опануванні труднощів сьогодні відводять життєздатності людини як показнику динамічної позитивної адаптації, як здатності не тільки вижити в складних умовах, а й досягти значущих цілей, розвиватися всупереч впливу зовнішніх негативних факторів. Життєздатність визначають як метаздатність, значущою характеристикою якої є активність самої людини. Така активність передбачає високу соціальну активність особистості, спрямовану на перетворення зовнішнього природного та соціального середовища 
і на формування самого себе відповідно до поставлених завдань [7]. Так, К. Шубникова наголошує на вирішальній ролі громадських форм активності, зокрема волонтерської діяльності, у формуванні життездатності особистості [8]. І. Ільїнський зазначає, що життєздатна особистість готова до формування смисложиттєвих настановлень відповідно до заданих цілей, займає активну громадянську позицію, відповідає нагальним запитам суспільства. Дослідник визначає життєздатність у єдності 3 такими якостями, як: відданість батьківщині та національній ідеї, воля до досягнення мети і вирішення життєвих завдань, відповідальне ставлення до власної діяльності, прагнення до успіху (наведено за [9]).

Не вирішені раніше частини загальної проблеми. Дослідження специфіки стратегій опанування має велике значення як для прогнозування ефективної адаптаційної поведінки під час переживання інтенсивного та хронічного стресу [10], так і для визначення шляхів відновлення життєздатності особистості, що зазнала травматизації.

Метою нашого дослідження стало визначення особливостей копінг-стратегій особистості, що зазнала впливу революційних подій Євромайдану.

Ми сформулювали такі вихідні гіпотези дослідження:

1. Копінг-стратегії особистості $\epsilon$ ефективним ресурсом опанування травми. Дієвість опанування виявляється в узгодженості копінгстратегій з факторами вияву життєздатності та ресурсів життєстійкості особистості в потенційно травматичних подіях.

2. Травматичні події спричинюють активацію ресурсів життєздатності, які можуть виконувати реабілітаційну функцію щодо збереження та відновлення психологічного здоров'я особистості.

Оскільки ресурси опанування та життєздатності повною мірою розкриваються в потенційно травматичних ситуаціях, ми як дослідники звернулися до революційних подій Євромайдану (2013-2014 роки). Адже, за експертними оцінками центру Разумкова, російсько-український конфлікт, що став їх продовженням, можна розглядати як справжній історичний злам, як безпрецедентне за масштабами відчуження двох народів, як виникнення “конфронтаційного вододілу” між двома країнами, як “травматичний досвід”, отриманий суспільствами обох країн. Такі ментальні зміни, на думку фахівців, мають глибинний, можливо навіть незворотній, характер [11].

Слід відмітити, що, з одного боку, події листопада 2013-го - лютого 2014-го істотно піднесли рівень протестної активності в столиці України, який було визнано “революційним”, а $з$ другого, ці події привертають увагу як приклад “показового вияву громадської самоорганізації” [12]. За висновками Національного інституту стратегічних досліджень, це вияв мобілізації у вигляді “українських громадянських практик”, а саме волонтерського руху [13]. 
У нашому дослідженні взяли участь 100 осіб віком від 17 до 80 років, серед них жінок - 82, чоловіків - 18. За віком досліджувані розподілилися так: 17-34 роки - 47 осіб, 35-80 років - 53 особи. Серед респондентів середню освіту мали 11 осіб, неповну вищу - 8, вищу 81 особа.

Методи дослідження.

1. Опитувальник "Способи опанувальної поведінки” (Адаптація методики WCQ), розроблений Р. Лазарусом і С. Фолкманом, адаптований Т. Крюковою та ін.

2. Авторський тест "Самооцінка життестійкості” (модифікація опитувальника Форверга на контактність).

3. Авторська анкета для визначення факторів вияву життєздатності в потенційно травматичних подіях (на прикладі подій Євромайдану 2013-2014 pp.).

Виклад основного матеріалу дослідження. На першому етапі емпіричного дослідження ми розробили анкету для визначення ресурсів життєздатності особистості (на прикладі подій Євромайдану 2013-2014рp.). За результатами анкетування було встановлено, що більш як половина (54\%) опитуваних позитивно сприймають ситуацію суспільно-політичних трансформацій в Україні. Майже половина (48\%) спостерігали за подіями у віртуальному просторі, а частка активістів Свромайдану становила $25 \%$. Переважна більшість (71\%) опитуваних пов'язують власне майбутнє з Україною. Майже половина (48\%) досліджуваних у ситуації ризику прагнуть захистити те, що в них $\epsilon$, убезпечити реалізацію життєвих планів, використовуючи такі соціально-психологічні форми контролю над ризиками, як гарантування безпеки. Переважна більшість (55\%) досліджуваних шукають соціальну підтримку в сім’і та родині, при цьому майже кожен третій респондент звик розраховувати переважно на власні ресурси.

Отже, було зауважено актуалізацію таких ресурсів життєздатності:

- позитивне ставлення до трансформаційних змін;

- соціально-політична активність;

- зв'язок власного майбутнього з батьківщиною;

- стратегії захисту від ризику у вигляді убезпечення реалізації власних життєвих планів;

- пошук соціальної підтримки в сім'ї та родині.

На другому етапі нашого дослідження визначалися особливості вияву копінг-стратегій залежно від активації ресурсів життєздатності. Для “вимірювання" копінгу ми застосували опитувальник Р. Лазаруса i С. Фолкмана, адаптований Т. Крюковою та ін. Він дає змогу визначити копінг-механізми, копінг-стратегії, способи опанування труднощів у різних сферах психічної діяльності. Опитувальник, який вважається першою стандартною методикою в галузі вимірювання копінгу, містить 
опис восьми ситуативно-специфічних стратегій опанування, серед яких: конфронтаційний копінг; пошук соціальної підтримки; планування розв' язання проблеми; самоконтроль; дистанціювання; позитивна переоцінка; взяття на себе відповідальності; втеча-уникнення [3]. Достовірність відмінностей між групами розраховувалася за допомогою непараметричного U-критерію Манна - Уітні. Для обробки результатів використовувалася статистична програма SPSS 13.0.

Отже, активісти Свромайдану в разі виникнення труднощів найчастіше звертаються до конфрантаиійного копінгу $(\mathrm{p}=0,006)$ і здебільшого орієнтовані на пошук соичіальної підтримки $(\mathrm{p}=0,059)$ і на позитивну переоцінку ( $\mathrm{p}=0,006)$. Респонденти, що спостерігали за подіями Свромайдану у віртуальному просторі, так само як і активісти, використовують конфронтацію $(\mathrm{p}=0,004)$ та пошук соціальної підтримки $(\mathrm{p}=0,025)$, але водночас демонструють звернення до таких копінгів, як самоконтроль ( втеча-уникнення ( $\mathrm{p}=0,035)$. Це може бути пов'язано з переживанням людиною сильного емоційного напруження та їі намаганням пом'ягшити вплив стрес-факторів. Респонденти, які намагаються захистити реалізацію власних життєвих планів, спрямовані на збереження безпеки, частіше звертаються до такого копінгу, як втеча-уникнення $(\mathrm{p}=0,048)$, що може бути пов'язано з високим рівнем тривоги за власне майбутнє і бажанням накопичити додаткові ресурси для захисту від очікуваних небезпек. Серед респондентів, які не пов'язують своє майбутнє з Україною, простежується тенденція до дистанціювання ( шення значущості проблеми, намагання кардинально змінити ситуацію, власні життєві умови. Респонденти, які відповіли, що хочуть навчатися/ працювати за кордоном, порівняно з тими, хто хоче навчатися/працювати в Україні, а також $з$ тими, хто ще не визначився, достовірно частіше вдаються до проблемно-фокусованих ( $\mathrm{p}=0,049)$ зусиль щодо змінення ситуації, керуються аналітичним підходом у розв’язанні проблем.

Наступним етапом нашого аналізу емпіричних даних було визначення особливостей використання копінг-стратегій залежно від компетенцій життєстійкості (рис. 1). Компетенції життєстійкості позитивно позначаються на здатності особистості утримувати довірчу взаємодію. Залученість людини в мережу довіри та взаєморозуміння зцілює особистість, сприяє відновленню ії цілісності, виконує стабілізаційну функцію щодо переживання наслідків травматичних подій, $є$ фактором оптимізації життєконструювання особистості.

Щоб оцінити рівень сформованості компетенцій життєстійкості, ми розробили тест “Самооцінка життєстійкості”. На основі концепції особистісних диспозицій життєстійкості С. Мадді було доповнено вихідний опитувальник М. Форверга та визначено відповідно такі шкали: емпатія; тепло, повага; щирість, справжність; ініціативність; рішучість; відповідальність; терпіння; оптимістичність; мобільність [14]. 


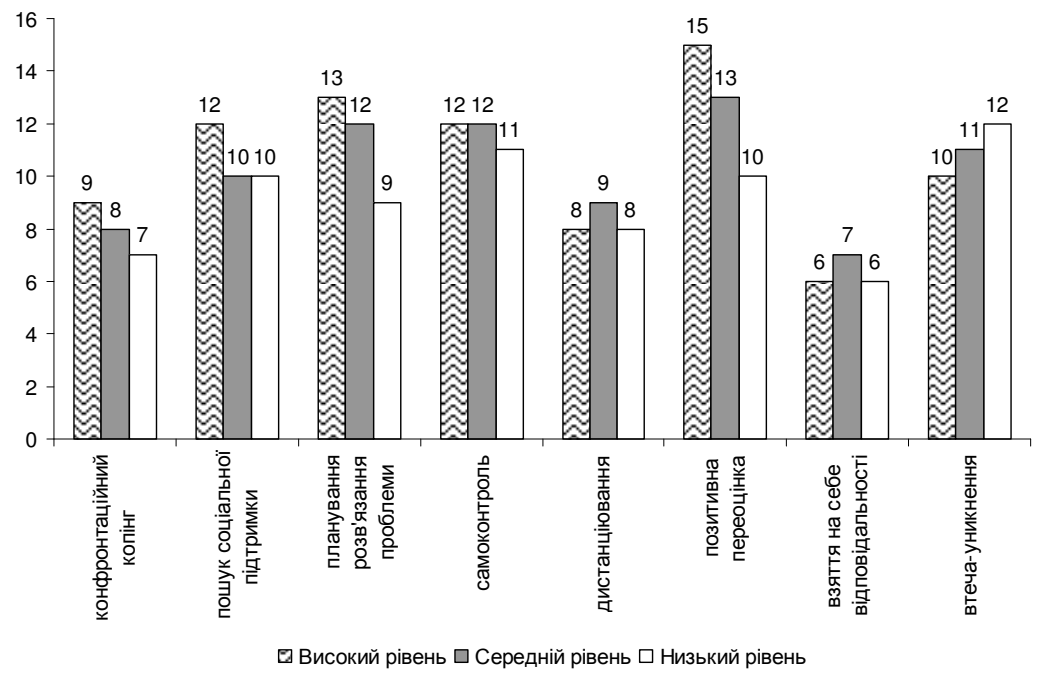

Puc 1. Особливості використання копінг-стратегій залежно від компетенцій життєстійкості

Для статистичної обробки достовірності різниці між групами обчислювався непараметричний U-критерій Манна - Уітні. Відтак результати опрацьовувалися за допомогою статистичної програми SPSS 13.0.

Отже, статистичне обчислення дало змогу визначити значущі відмінності між респондентами. На рівні достовірності спостерігаються значущі відмінності між респондентами, які мають високий і середній рівень сформованості компетенцій життєстійкості, і тими, хто має низький рівень при опануванні труднощів. Респонденти з високим i середнім рівнем життєстійкості частіше використовують такі копінгстратегії, як “планування розв' язання проблеми” ( $p=0,006)$, “позитивна переоцінка" ( $\mathrm{p}=0,012)$ та “пошук соціальної підтримки” ( $=0,006)$. Отож можемо припустити, що життєстійкість зумовлює використання проблемно орієнтованих копінгів, аналітичного підходу до розв'язання проблеми, здатність покладатися на соціальну підтримку в доланні життєвих труднощів і зосереджуватися на зростанні власної особистості, готовність до позитивного переосмислення складної ситуації.

Далі ми проаналізували, яким чином співвідносяться ресурси життєздатності, зокрема ставлення до суспільно-політичних трансформацій в Україні, з компетенціями життєстійкості (рис. 2). 3'ясувалося, що респонденти, які позитивно налаштовані на трансформаційні зміни в країні, порівняно з тими, хто займає нейтральну позицію, помітно частіше виявляють такі провідні якості, як щирість $(\mathrm{p}=0,032)$, рішучість $(\mathrm{p}=0,025)$, відповідальність $(\mathrm{p}=0,011)$, оптимістичність $(\mathrm{p}=0,046)$. 


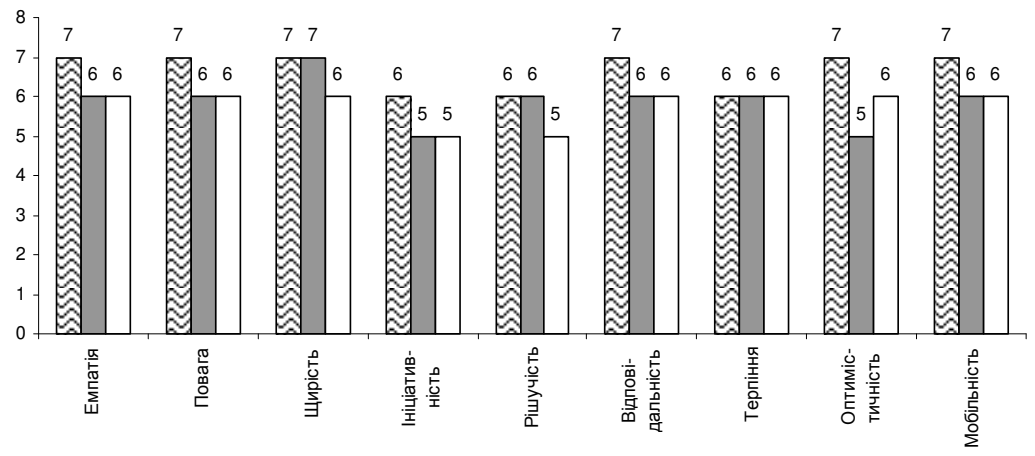

$\square$ Позитивне $\square$ Негативне $\square$ Нейтральне

Puc. 2. Взаємозв' язок ставлення до суспільно-політичних трансформацій в Україні з компетенціями життєстійкості

Наступним етапом аналізу було визначення особливостей взаємозв'язку між рівнем громадянської активності і компетенціями життєстійкості (рис. 3). Статистичні відмінності між групами респондентів свідчать про те, що в громадських активістів порівняно 3 тими, хто не брав участь у подіях 2013-2014 років, більш розвинута така якість, як повага ( $\mathrm{p}=0,035)$. Відповідно, ті респонденти, які не брали участь, більшою мірою виявляють у спілкуванні таку якість, як терпіння $(\mathrm{p}=0,034)$. Також було визначено достовірну різницю між активістами і тими, хто спостерігав за подіями у віртуальному просторі. Отже, активісти демонструють більшу “рішучість" ( $\mathrm{p}=0,021)$, а ті респонденти, що спостерігали за подіями у віртуальному просторі, - “терпіння" (p = 0,049).

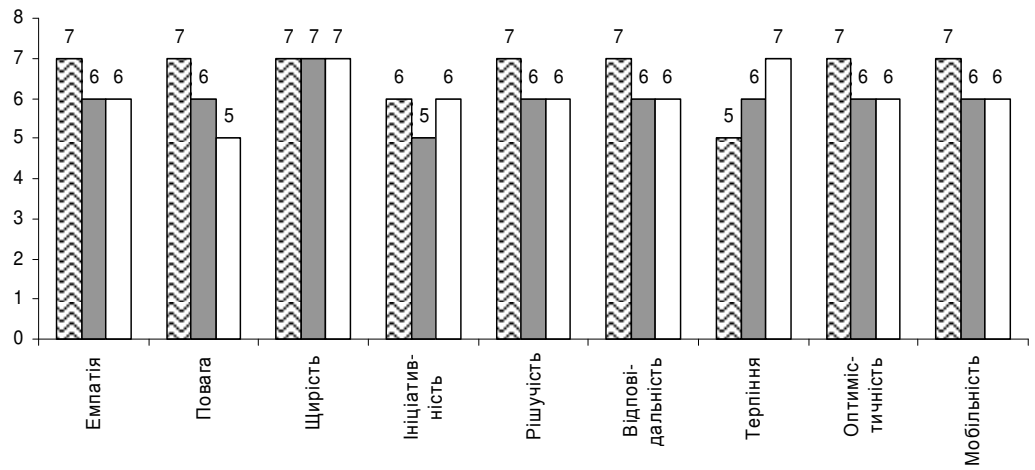

凶 Брав активну участь $\square$ Спостерігав за подіями у віртуальномупросторі $\square$ Не брав участь

Рис. 3. Особливості взаємозв'язку між рівнем громадянської активності і компетенціями життєстійкості 
Поряд 3 цим було обчислено статистичні відмінності між формами стабілізації ризику і компетенціями життестійкості (рис. 4). Виявлено, що для респондентів, які обирають таку форму стабілізації ризику, як “випробування себе і власних сил”, порівняно з тими, хто обирає інші форми захисту від ризику, а саме "убезпечення реалізації власних життєвих планів", провідними є компетенції “щирість” ( $=0,021)$, "ініціативність" ( $p=0,001)$, "рішучість" $(p=0,002)$ та "оптимістичність" $(\mathrm{p}=0,001)$.

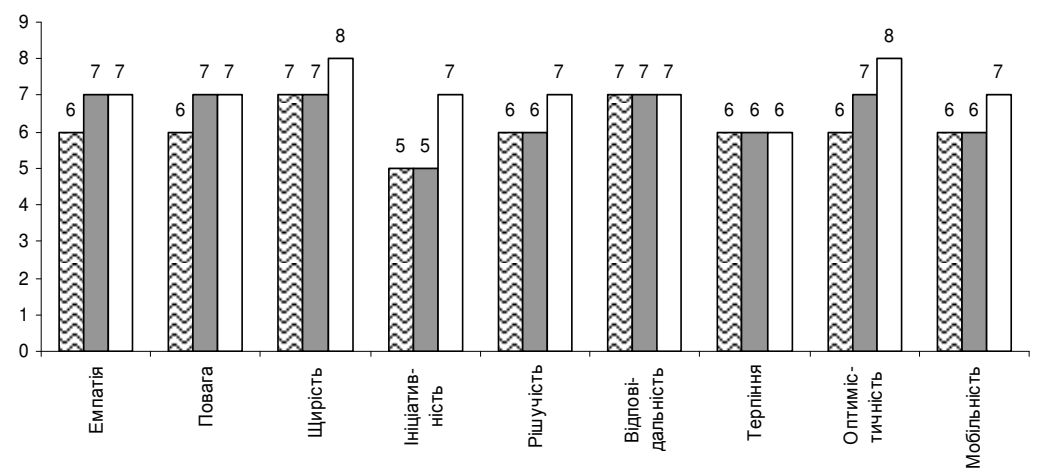

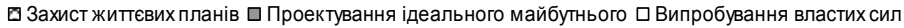

Рuc. 4. Особливості взаємозв'язку між формами стабілізації ризику і компетенціями життєстійкості

Також було зауважено достовірну відмінність між респондентами, які в складних ситуаціях звертаються за підтримкою до друзів і знайомих, i тими, хто в складних ситуаціях звик розраховувати на власні сили. Отже, респонденти, що зазвичай покладаються на власні сили, мають більш розвинену компетентність життєстійкості “мобільність" $(\mathrm{p}=0,034)$.

Визначено вікові особливості опанування складної ситуації: молодь у разі зіткнення з труднощами виявляє “рішучість", а більш зрілі та літні люди - “оптимістичність” та “відповідальність".

Серед конструктивних факторів опанування досліджувався i вплив рівня освіти. Встановлено, що респонденти з вищою освітою, стикаючись із життєвими труднощами, частіше вдаються до таких копінг-стратегій, як “пошук соціальної підтримки”, “планування розв'язання проблеми" та "позитивна переоцінка" (фокусування на зростанні власної особистості).

Виявилося, що жінки частіше, ніж чоловіки, вдаються до такого копінгу, як “позитивна переоцінка" ( $\mathrm{p}=0,006)$, тобто вони в скрутній ситуації більш схильні спрямовувати свої зусилля на позитивну переоцінку ситуації та фокусуватися на зростанні власної особистості. 
Що ж до вікових відмінностей у використанні копінг-стратегій, то з'ясувалося, що респонденти віком 35-45 років достовірно частіше схиляються до “втечі-уникнення" ( $\mathrm{p}=0,045)$, ніж респонденти старшого віку (60-78 років) ( $\mathrm{p}=0,047)$. Використання респондентами, що перебувають на етапі кульмінації життєвого шляху, на піку своєї соціальної активності, стратегії уникнення, може перешкоджати адекватному когнітивному оцінюванню цією віковою категорією пережитих подій i підвищує ризик того, що травматичний досвід не буде повною мірою інтегрований у свідомість.

\section{Висновки}

1. Вияв конфронтаційних навичок, готовність до ризику в поєднанні з готовністю відстоювати активну громадянську позицію можна вважати адекватною щодо революційної ситуації стратегією подолання та нейтралізації дії зовнішніх руйнівних факторів. Однак така стратегія може спричиняти підвищений ризик емоційного вигоряння.

2. Взяття на себе відповідальності за вирішення проблемної ситуації, розвинуті навички самоконтролю в поєднанні з мотивацією уникнення від активної протидії можуть бути показником незбалансованості компонентів копінг-механізмів (емоційного, когнітивного та поведінкового), певним виявом емоційної ригідності.

3. Середній та високий рівень сформованості компетенцій життєстійкості зумовлює високу ефективність використання копінг-стратегій. Серед них - проблемно орієнтовані копінги, пошук соціальної підтримки, розвиток власної особистості, готовність до позитивного переосмислення складної ситуації.

4. Позитивне ставлення до трансформацій у суспільстві корелює 3 такими якостями життестійкості, як щирість, рішучість, відповідальність та оптимістичність. 3 огляду на результати дослідження можна стверджувати, що майже половина респондентів має у своєму арсеналі ефективні ресурси опанування.

5. Позиція уникнення активної протидії руйнівним факторам корелює $з$ такою якістю життєстійкості, як терпіння. Це може свідчити, 3 одного боку, про низьку усвідомлюваність руйнівного впливу, а з другого - про власну впевненість у здатності тривалий час витримувати важкі життєві умови.

6. Готовність випробувати власні сили корелює із щирістю, ініціативністю, рішучістю та оптимістичністю, що дає підстави розглядати цю форму опанування ризику як адекватний копінг-ресурс протидії негативним, руйнівним впливам ситуації.

7. Пошук соціальної підтримки $є$ універсальним копінг-ресурсом опанування наслідків травматичних подій. Але, слід зазначити, покладання на власні сили в ситуації ризику забезпечує вищу мобільність, що може бути більш корисним 3 погляду вирішення поставлених 
життєвих завдань та підтримання нормального життєконструювання в складній ситуації.

8. Існують вікові відмінності у використанні копінг-стратегій. Респонденти віком 35-45 років є групою, щодо якої слід застосовувати більш інтенсивні психологічні інтервенції. Представники цієї групи, переживаючи етап кульмінації життєвого шляху, вдаються зазвичай до захисних копінг-механізмів, що може перешкоджати адекватному когнітивному оцінюванню ситуації та інтеграції травматичного досвіду у свідомість, а також уповільнювати дію механізмів нормальної життєпобудови.

Напрямки подальших розвідок. Отримані результати щодо особливостей вияву копінг-стратегій особистості, що переживає наслідки травматичних подій, $є$ підгрунтям для розроблення технологій i засобів реабілітації осіб, що потребують психологічної допомоги та підтримки.

\section{Список використаних джерел}

1. Нартова-Бочавер, С. К. (1997). “Сoping - behavior” в системе понятий психологии личности. Психологический журнал, 18(5), 20-30.

2. Никольская, И. М., \& Грановская, Р. М. (2006). Психологическая защчита у детей. Санкт-Петербург: Речь.

3. Крюкова, Т. Л., \& Куфтяк, Е. В. (2007). Опросник способов совладания с ТЖС (адаптация методики WCQ). Журнал практического психолога, 3, 93-112.

4. Анцыферова, Л.И. (1994). Личность в трудных жизненных условиях: переосмысливание, преобразование ситуаций и психологическая защита. Психологический журнал, 15(1), 3-19.

5. Joseph, S., \& Linley, P. A. (2006). Growth following adversity: Theoretical perspectives and implications for clinical practice. Clinical Psychology Review, 26, 1041-1053.

6. Hobfoll, S. E. (1996). Social Support: Will You Be There When I Need You? In N. Vanzetti, \& S. Duck (Eds.), A Lifetime of Relationships (pp. 46-74). Belmont, CA: Thomson Brooks/Cole Publishing Co.

7. Лактионова, А. И. (2013). Структурно-уровневая организация жизнеспособности как метаспособности. Личность профессионала в современном мире (с. 109-127). Москва: Ин-т психологии РАН.

8. Шубникова, Е. Г. (2014). Формирование жизнеспособности личности будущих педагогов на основе волонтерской деятельности. Современные проблемы науки и образования, 3. Взято из https:/www.science-education.ru/ pdf/2014/3/487.pdf.

9. Андрущенко, О. Н. (2017). Жизнеспособность подростков. Евразийский научный журнал, 1/1. Взято из http://journalpro.ru/articles/zhiznesposobnostpodrostkov/.

10. Тарабрина. Н. В., \& Хажуев, И. С. (2015). Посттравматический стресс и защитно-совладающее поведение у населения, проживающего в условиях длительной чрезвычайной ситуации. Экспериментальная психология, 8(3), 215-226. 
11. Російсько-український конфлікт: стан, наслідки, перспективи розвитку подій (Аналітична доповідь Центру Разумкова). (2014). Національна безпека i оборона, 5-6 (148-149), 2-40. Взято з http://www.razumkov.org.ua/uploads/ journal/ukr/NSD148-149_2014_ukr.pdf.

12. Мордавець, М.В. (2014). Громадянська активність в Україні: динаміка та основні форми. Актуальні проблеми політики, 53, 241-252. Взято 3 http://nbuv.gov.ua/UJRN/appol_2015_53_31.

13. Горєлов, Д. М., \& Корнієвський, О. А. (2015). Волонтерський рух: світовий досвід та украӥнські громадянські практики: аналітична доповідь. Національний інститут стратегічних досліджень. Київ. Взято 3 http://www.niss. gov.ua/content/articles/files/volonter-697e4.pdf.

14. Титаренко, Т. М., \& Ларіна, Т. О. (2009). Життєстійкість особистості: соиіальна необхідність та безпека. Київ: Марич.

\section{References}

1. Nartova-Bochaver, S. K. (1997). "Coping - behavior" v sisteme ponyatiy psikhologii lichnosti ["Coping - behavior" in the system of concepts of the psychology of personality]. Psikhologicheskiy zhurnal [Psychological journal], 18(5), 20-30 (rus).

2. Nikolskaya, I. M., \& Granovskaya, R. M. (2006). Psikhologicheskaja zashchita $u$ detey [Psychological protection in children]. St. Petersburg: Rech Publ. (rus).

3. Kryukova, T. L., \& Kuftyak, Ye. V. (2007). Oprosnik sposobov sovladaniya s TZhS (adaptatsiya metodiki WCQ) [Questionnaire of ways of coping with TJS (adaptation of the WCQ methodology)]. Zhurnal prakticheskogo psikhologa [Journal of Practical Psychology], 3, 93-112 (rus).

4. Antsyferova, L. I. (1994). Lichnost v trudnykh zhiznennykh usloviyakh: pereosmyslivaniye, preobrazovaniye situatsiy i psikhologicheskaya zashchita [Personality in difficult living conditions: re-thinking, transformation of situations and psychological protection]. Psikhologicheskiy zhurnal [Psychological journal], 15(1), 3-19 (rus).

5. Joseph, S., \& Linley, P. A. (2006). Growth following adversity: Theoretical perspectives and implications for clinical practice. Clinical Psychology Review, 26, 1041-1053.

6. Hobfoll, S. E. (1996). Social Support: Will You Be There When I Need You? In N. Vanzetti, \& S. Duck (Eds.), A Lifetime of Relationships (pp. 46-74). Belmont, CA: Thomson Brooks/Cole Publishing Co.

7. Laktionova, A. I. (2013). Strukturno-urovnevaya organizatsiya zhiznesposobnosti kak metasposobnosti [Structural-level organization of forming the resilience of the personality of future teachers on the basis of volunteer activity as a metaability]. Lichnost professionala $v$ sovremennom mire [The personality of a professional in the modern world] (pp. 109-127). Moscow: Institute of Psychology RAS (rus).

8. Shubnikova, Ye. G. (2014). Formirovaniye zhiznesposobnosti lichnosti budushchikh pedagogov na osnove volonterskoy deyatelnosti [Forming the resilience of the personality of future teachers on the basis of volunteer activityof the personality of future teachers on the basis of volunteer activity]. Sovremennyye problemy nauki i obrazovaniya [Modern problems of science and education], 3, 1-8. Retrieved from https://www.science-education.ru/pdf/2014/3/487.pdf (rus). 
9. Andrushchenko, O. N. (2017). Zhiznesposobnost podrostkov [Resilience of adolescents]. Yevraziyskiy nauchnyy zhurnal [Eurasian Scientific Journal], 1/1. Retrieved from http://journalpro.ru/articles/zhiznesposobnost-podrostkov/ (rus).

10. Tarabrina, N. V., \& Hazhuyev, I. S. (2015). Posttravmaticheskiy stress i zashchitnosovladayushcheye povedeniye $\mathrm{u}$ naseleniya, prozhivayushchego $\mathrm{v}$ usloviyakh dlitelnoy chrezvychaynoy situatsii [Post-traumatic stress and protective-coping behavior in a population living in a prolonged emergency situation]. Eksperimentalnaya psikhologiya [Experimental Psychology], 8(3), 215-226 (rus).

11. Rosiisko-ukrainskyi konflikt: stan, naslidky, perspektyvy rozvytku podii (Analitychna dopovid Tsentru Razumkova) [Russian-Ukrainian conflict: state, consequences, prospects for the development of events (Analytical report of the Razumkov Center)] (2014). Natsionalna bezpeka i oborona [National Security and Defense], 5-6 (148-149), 2-40. Retrieved from http://www.razumkov.org.ua/ uploads/journal/ukr/NSD148-149_2014_ukr.pdf (ukr).

12. Mordavets, M. V. (2014). Hromadianska aktyvnist v Ukraini: dynamika ta osnovni formy [Civic activism in Ukraine: dynamics and basic forms]. Aktualni problemy polityky [Actual problems of politics], 53, 241-252. Retrieved from http://nbuv. gov.ua/UJRN/appol_2015_53_31 (ukr).

13. Horielov, D. M., \& Korniievskyi, O. A. (2015). Volonterskyi rukh: svitovyi dosvid ta ukrainski hromadianski praktyky: analitychna dopovid [Volunteer Movement: Global Experience and Ukrainian Civic Practices: analytical note]. Kyiv. Retrieved from http://www.niss.gov.ua/content/articles/files/volonter-697e4.pdf (ukr).

14. Tytarenko, T. M., \& Larina, T. O. (2009). Zhyttiestiikist osobystosti: sotsialna neobkhidnist ta bezpeka [Hardiness of the person: social necessity and safety]. Kyiv: Marych Publ. (ukr).

С Ларіна Т. О. 